\title{
Assessment of the management of the Family Health Strategy via the tool Assessment for Quality Improvement in municipalities of Minas Gerais, Brazil
}

\author{
Andreza Viana Lopes Cardoso ${ }^{1}$ \\ Ana Paula Nascimento Chain ${ }^{2}$ \\ Rafael Inácio Pompeu Mendes ${ }^{2}$ \\ Efigênia Ferreira e Ferreira ${ }^{1}$ \\ Andréa Maria Duarte Vargas ${ }^{1}$ \\ Andréa Maria Eleutério de Barros Lima Martins ${ }^{2}$ \\ Raquel Conceição Ferreira ${ }^{1}$
}

${ }^{1}$ Departamento de Odontologia Social e Preventiva, Universidade Federal de Minas Gerais. Av. Antônio Carlos 6627, Pampulha. 31270-901 Belo Horizonte MG Brasil. andrezavlc@gmail.com ${ }^{2}$ Departamento de Odontologia, Centro de Ciências Básicas e da Saúde, Universidade Estadual de Montes Claros.

\begin{abstract}
The self-assessment of the quality ofthe Family Health Strategy(FHS) was assessed in the context ofmanagement and its correlation with characteristics of FHS and of the municipality. Managers, coordinators and Family Health Unit managers of municipalities in the Northeast region of Minas Gerais replied with tools 1, 2 and 3 of the Assessment for Improving the Quality of Family Health Strategy (AIQ). Scores were defined for each subdimension, according to the number of features compliant with the standards of the AIQ. We tested the correlation of this score with coverage and the deployment time of the FHS, with the municipal population and the HDI (Human Development Index). The lowest scores were for Work Management, Permanent Education and Inputs, Immunobiologicals and Medicines. There was a positive correlation between the municipal population and Strengthening of Coordination, Support for Teams, Permanent Education Management and Standardization and a negative one with Infrastructure and Equipment. The use of the AIQ tools permitted the identification of subdimensions and municipalities which will require greater attention and intervention by the municipal management.

Key words Assessment of health services, Primary Healthcare, Health management, Family Health Program
\end{abstract}




\section{Introduction}

The expansion of the Family Health Strategy (FHS) has initiated a discussion on questions regarding the qualification of teams and the resolvability of services, highlighting the need for monitoring and assessment of Primary Healthcare (PHC) ${ }^{1}$. To this end, the Ministry of Health $(\mathrm{MoH})$ has begun to argue in favor of the continuous upgrading of assessment processes in the routine of management and of health services ${ }^{2}$. The Policy of Monitoring and Assessment of the Basic Healthcareestablished the Assessment for Improving the Quality of the Family Health Strategy(AIQ) ${ }^{3}$, in conjunction with states and municipalities, locating assessment as a permanent instrument for decisionmaking andquality as a fundamental attribute to be achieved in the Single Health System (SUS) ${ }^{4}$.

Donabedian's model was adopted as a conceptual reference for the elaboration of the AIQ. This model considers elements of structure, process and results, which are related to the assessment elements of the FHS teams: structure - inputs, teams, materials, human resources, physical environment and normative organization; process - organizational, technical-scientific and interpersonal aspects; result - access, adjustment and effectiveness forthe promotion of changes in the health of the population ${ }^{4}$.

As a support for the assessment, the $\mathrm{MoH}$ developed self-assessment tools, directed towards the municipal managementof health, the municipal coordinationof the FHS, the manager responsible for managing the Family Health Units (FHU) and the FHS Teams. They seek a diagnosis for the organization and functioning of the services and their practices on the basis of the principles, directives and fields of action of the FHS. The AIQ considers two major integrated units of analysis: Management and Team, containing dimensions of analysis, which are in turn broken down into subdimensions. Each subdimension has its quality standards, amounting to 300 standards in five tools.

The AIQ has sought to promote, as the principal objective of its deployment, the monitoring and assessment of the quality stages of the FHS, making available tools for the diagnosis of problems and stimulating the debate on improvements in the field ofhealth, based on the results of the self-assessment processes. These processes may be adhered to freely by themanagers and do not determine financial incentives or sanctions for the municipalities and teams which have adhered to the programme ${ }^{4}$.
An effort was nevertheless made to facilitate a broader program, which could permit the expansion of access and the improvement in the quality ofBasic Healthcare (BH) throughout Brazil, with the guarantee of a quality standard that was comparable, nationally, regionally and locally and greater transparency and effectiveness of the government actions intended for $\mathrm{BH}^{5}$.

In order to achieve such objectives, the $\mathrm{MoH}$ introduced the National Program for Improvement of Access and Quality (PIAQ), via Decree No. 1.654 GM/MS, of 19 July 2011, which was the result of an extensive and important process of negotiation between the three spheres of management of the SUS . The PIAQ may also be adhered to freely, although it links financial resources to the meeting of goals, previously established by the contractualization of objectives ${ }^{5}$.

Self-assessment, which is the final objective of the AIQ, is understood is the point of departure for the developmentphase of the PIAQ, which possessesthree other phases, which complement each other and conform to a continuous cycle (Adhesion and Contractualization; Development; External Assessmentand Recontractualization $)^{5}$.

While other assessment instruments have been developed, the AIQ takes into account many of the assessment dimensions contained in the PIAQ, maintaining similar theoretical constructions, which seek a discussion of the quality of management and of teams as central units of analysis in the assessment questionnaires ${ }^{4,5}$. As such, studies on the AIQ are valid and relevant, since this instrument may generate assessment indicators for the quality of FHS in Braziland even today, only a small number of studies have used this assessment instrument as a central theme of study ${ }^{6-8}$.

Minas Gerais is a Brazilian state with social inequalities between its regions ${ }^{9}$. TheNortheast macroregion, composed of 63 municipalities $^{10}$, is one of the poorest regions in the State, with major social inequality and a predominantly rural population ${ }^{11}$. Assessing the quality of PHC in this situation is essential for establishing the response capacity of policies, programs and services to the healthcare needs of the population, principally in a context of scarce public resources for the health sector. In addition, considering the need to monitor the PHC, as well as the important role of the manager, of the municipal coordinator of the FHS and of the FHU managers in promoting, protecting and restoring the health of its residents, the self-assessment of the quality of FHS 
in the municipalities of the Northeast macroregion of Minas Geraisis justified in the context of management.

This study assessed the quality of the FHS, considering the AIQ cited by the managers, municipal coordinators of the FHS and managers of the FHU in the municipalities of the Northeast macroregion of Minas Gerais, and verified the correlation between the self-assessment scores and the Human Development Index (HDI), the municipal population, coverage and deployment time of the FHS.

\section{Methodology}

An ecological study, executed in the 63 municipalities of the healthcare macroregion of the Northeast of Minas Gerais, covering theMucuri and Jequitinhonha Valleys in geographical terms, subdivided into eight health microregions ${ }^{10}$. This macroregion has a territorial area of $56,641 \mathrm{~km}^{2}$, a population density of 14.33 inhabitants $/ \mathrm{km}^{2}$ and an estimated populationin 2011 of 811,856 inhabitants ${ }^{10}$. In territorial terms, it is similar to the Centremacro region, in which the capital Belo Horizonte is located. In this latter macro region, however, population density is 105.49 inhabitants $/ \mathrm{km}^{2}$ with an estimated populationin 2011 of $6,145,218$ inhabitants $^{10}$. The average HDI of the Northeast macroregion is 0.636 , considered as an average human development value. Minas Gerais has a high HDI value, of 0.731; like Brazil, with a HDI of $0.744^{12}$.

The Northeast macroregion covers the Regional Health Superintendencies (SRS) of Teófilo Otoni, Diamantina and the Regional Health Management Area (GRS) of Pedra Azul. The SRS of Teófilo Otoni covers 32 municipalities; 25 municipalities are under the jurisdiction of the GRS of Pedra Azul and six belong to the jurisdiction of the SRS of Diamantina and comprise the micro region of Araçuai ${ }^{13}$. At the time of collection of the data, the 63 municipalities had 264 FHS teams (February to April 2011). This included all of the managers, municipal coordinators of the FHS and managers of the FHU of the 63 municipalities, holding the position during the period of February/March2011, forming a group of 63 managers, 63 municipal FHS coordinators and 264 FHU managers.

The quality of the FHS was assessed by the three players involved in the management of the FHS through tools 1, 2 and 3 of the AIQ, which correspond to the threedimensions: Develop- ment of the FHS, Technical Coordination of Teams and theFamily Health Unit ${ }^{4}$.

Tool 1, aimed at the municipal health manager, assessed the dimension Development of the FHS, with 60 standards, organized into four subdimensions: Deployment/Implementation of the FHS in the municipality; Integration of the Service Network; Work Management and Strengthening of Coordination. The dimension Technical Coordination of Teams (tool 2), assessed by the coordinators of the FHS, included thesubdimensions: Planning and Integration; Support for Teams; Permanent Education Management; Management of the Assessment and Standardization, distributed across 40 standards. The Family Health Unit dimension (tool 3), with 40 standards in two subdimensions, Infrastructure and Equipment of the FHU and Inputs, Immunobiologicals and Medicines, was directed towards the managers of the FHU. The quality standards in each subdimension are accompanied by their description, which determines the characteristics necessary for ensuring that the FHS is or is not compliant with that standard ${ }^{4}$.

Initially, the project was disclosed to themanagers during the meetings of the Bipartite Intermanager Commissions (CIB) of the eight health microregions. The questionnaires intended for the managerswere distributed to them, with the managers requested to forward those intended for the coordinators and the FHU managers of the municipalities under their management.

The following information was also collected from the municipalities: population in 2010, from the Instituto Brasileiro de Geografia e Estatística [Brazilian Institute of Geography and Statistics] (IBGE) ${ }^{9}$; HDI in the Atlas of Human Development of Brazil, of $2000^{12}$; and time of deployment and population coverage of the FHS, on the website of the MoH/Department of Basic Healthcare, referring to March $2011^{14}$.

The data were analyzed using the statistical package SPSS for Windows v. 17.0, considering the municipality as the unit of analysis. For each municipality, the number of features compliant and non-compliant with the standards referring to the assessed subdimensions and dimensions was calculated, in order to obtain the average standard deviation of the compliance scores. In the case of tool 3, each FHU presented an adjustment score to the assessed subdimensions. Following this, for each municipality, the average of the compliance scores obtained for each of the FHUs was calculated for each municipality. The correlation between the scores of the subdimen- 
sions of each dimension and the variables referring to the municipalities and to the FHS was investigated by calculating the Spearman correlation coefficient $(\mathrm{p}<0.05)$. The frequency of municipalities or FHUs in compliance with each of the standards was obtained for all of the assessed dimensions/subdimensions.

The research project was approved by the Research Ethics Committee of the State University of Montes Claros. All of the participants signed the free and informed consent form.

\section{Results}

There was a response rate of 79.4\% $(n=50)$ and of $76.2 \%(n=48)$ among themanagers and coordinators respectively. With regard to the participation of FHU managers, in eight municipalities there was a loss of $100 \%$. All in all, 55 municipalities (87.3\%) and 210 managers of the FHU (79.5\%) replied.

Table 1 also demonstrates the management assessment of the FHS with regard to the three dimensions of the AIQ. In the dimension Development of the FHS, the managers assessed the subdimensionWork Management and Strengthening of Coordination more negatively, which presented the lowest average proportional scores. The best average performance was obtained by the Deployment/Implementation subdimension of the FHS in the municipality. For the dimension Technical Coordination of Teams, the maximum score for compliance with the standards was only missed by the Planning and Integration subdimension. In this dimension, the coordinators had a more negative assessment of the Permanent Education Management subdimension. The best proportional average performance was obtained in the Support for Teams subdimension. In the Family Health Unit dimension, in proportional terms the Inputs, Immunobiologicals and Medicines subdimension received a better assessment by the managers of the FHU than the Infrastructure and Equipment of the FHU dimension.

The municipalities with higher population reported significantly higher compliance scores in the subdimension Strengthening of Coordination, Support for Teams, Permanent Education Management and Standardization. The scores for the subdimensions Infrastructure and Equipment of the FHU and Inputs, Immunobiologicals and Medicines were significantly lower in municipalities with a higher population. The municipalities with a higher HDI presented lower scores for the subdimension Inputs, Immunobiologicals and Medicines (Table 2).

In the Deployment/Implementation subdimension for FHS within the municipality, the percentages of municipalities compliant with the standards of the AIQ varied from $42 \%$ to $100 \%$,

Table 1. Assessment of the Development dimensions of the Family Health Strategy, Technical Coordination of Teams and Family Health Unit by the managers $(n=50)$, coordinators $(n=48)$ and managers of the UFH $(n=$ 55) of the Northeast region of Minas Gerais. Minas Gerais. 2011.

\begin{tabular}{|c|c|c|c|c|c|}
\hline \multirow{2}{*}{ Dimension $^{*}$} & \multirow{2}{*}{ Subdimension } & \multirow{2}{*}{$\begin{array}{c}\text { Maximum } \\
\text { compliance } \\
\text { score }\end{array}$} & \multicolumn{3}{|c|}{ Compliance scores } \\
\hline & & & Minimum & Maximum & Average (SD) \\
\hline $\begin{array}{l}\text { Development } \\
\text { of the Family }\end{array}$ & $\begin{array}{l}\text { Installation/Implementation of FH } \\
\text { within the municipality }\end{array}$ & 19 & 11 & 19 & $16.08(2.01)$ \\
\hline \multirow[t]{3}{*}{ Health Strategy } & Integration of the services network & 19 & 5 & 19 & $13.50(13.80)$ \\
\hline & Work Management & 10 & 1 & 9 & $4.50(1.88)$ \\
\hline & Strengthening of Coordination & 12 & 1 & 12 & $7.56(2.58)$ \\
\hline Technical & Planning and Integration & 8 & 0 & 7 & $5.00(1.52)$ \\
\hline Coordination & Monitoring of the Teams & 7 & 0 & 7 & $5.50(1.52)$ \\
\hline \multirow[t]{3}{*}{ of Teams } & Management of Permanent Education & 6 & 0 & 6 & $3.54(1.61)$ \\
\hline & Management of Valuation & 10 & 0 & 10 & $6.77(2.22)$ \\
\hline & Standardization & 9 & 0 & 9 & $5.69(2.23)$ \\
\hline \multirow{3}{*}{$\begin{array}{l}\text { Family Health } \\
\text { Unit }\end{array}$} & Infrastructure and Equipment of the & 24 & 8 & 22 & $14.42(3.62)$ \\
\hline & Family Health Unit & & & & \\
\hline & $\begin{array}{l}\text { Inputs, Immunobiologicals and } \\
\text { Medicines }\end{array}$ & 16 & 6 & 16 & $13.23(2.38)$ \\
\hline
\end{tabular}


Table 2. Spearman Correlation between compliant scores for the Development dimensions of the Family Health Strategy, Technical Coordination of Teams and Family Health Unit and characteristics of the municipality and of FHS. Minas Gerais. 2011.

\begin{tabular}{|c|c|c|c|c|c|c|c|c|c|}
\hline \multirow{2}{*}{ Dimension } & \multirow{2}{*}{ Subdimension } & \multicolumn{2}{|c|}{$\begin{array}{c}\text { Population } \\
\text { of the } \\
\text { municipality }\end{array}$} & \multicolumn{2}{|c|}{$\begin{array}{c}\text { Percentage } \\
\text { coverage by } \\
\text { the FHS }\end{array}$} & \multicolumn{2}{|c|}{$\begin{array}{l}\text { HDI of the } \\
\text { municipality }\end{array}$} & \multicolumn{2}{|c|}{$\begin{array}{l}\text { Installation } \\
\text { time of FHS }\end{array}$} \\
\hline & & $\boldsymbol{r}$ & $\begin{array}{c}\mathrm{p} \\
\text { value }\end{array}$ & $\boldsymbol{r}$ & $\begin{array}{c}\mathrm{p} \\
\text { value }\end{array}$ & $\boldsymbol{r}$ & $\begin{array}{c}\mathrm{p} \\
\text { value }\end{array}$ & $\boldsymbol{r}$ & $\begin{array}{c}\mathrm{p} \\
\text { value }\end{array}$ \\
\hline \multirow[t]{5}{*}{$\begin{array}{l}\text { Development } \\
\text { of FHS }\end{array}$} & $\begin{array}{l}\text { Installation/Implementation of FH } \\
\text { within the municipality }\end{array}$ & -0.09 & 0.55 & 0.10 & 0.49 & 0.17 & 0.23 & 0.10 & 0.55 \\
\hline & Integration of the services network & 0.10 & 0.51 & 0.02 & 0.89 & 0.04 & 0.79 & 0.14 & 0.34 \\
\hline & Work Management & 0.07 & 0.65 & 0.01 & 0.94 & 0.10 & 0.50 & 0.09 & 0.52 \\
\hline & Strengthening of Coordination & 0.29 & 0.04 & 0.15 & 0.30 & 0.02 & 0.91 & 0.13 & 0.38 \\
\hline & Planning and Integration & 0.23 & 0.11 & 0.12 & 0.41 & 0.09 & 0.53 & 0.19 & 0.21 \\
\hline Technical & Monitoring of the Teams & 0.29 & 0.04 & 0.05 & 0.74 & 0.14 & 0.35 & 0.01 & 0.99 \\
\hline \multirow[t]{3}{*}{$\begin{array}{l}\text { Coordination } \\
\text { of Teams }\end{array}$} & $\begin{array}{l}\text { Management of Permanent } \\
\text { Education }\end{array}$ & 0.63 & 0.00 & 0.26 & 0.08 & 0.18 & 0.21 & 0.02 & 0.90 \\
\hline & Management of Valuation & 0.18 & 0.22 & 0.20 & 0.18 & 0.03 & 0.87 & 0.01 & 0.94 \\
\hline & Standardization & 0.38 & 0.01 & 0.09 & 0.55 & 0.08 & 0.61 & 0.08 & 0.57 \\
\hline Family & $\begin{array}{l}\text { Infrastructure and Equipment of } \\
\text { the Family Health Unit }\end{array}$ & -0.43 & 0.00 & 0.15 & 0.28 & 0.60 & 0.07 & 0.23 & 0.09 \\
\hline Health Unit & $\begin{array}{l}\text { Inputs, Immunobiologicals and } \\
\text { Medicines }\end{array}$ & -0.59 & 0.00 & 0.21 & 0.12 & -0.27 & 0.04 & 0.22 & 0.11 \\
\hline
\end{tabular}

$r=$ Spearman correlation coefficient.

with the lowest two percentages obtained for the standards "The municipal health manager has formalized agreements and/or partnerships with organizations of civil society and/or social movements" (42\%) and "The FHS is institutionalized through a legal instrument" (62\%). The percentages of municipalities compliant with the standards of the subdimension Integration of the Service Network varied from 30\% to $96 \%$. $30 \%$ and $48 \%$ of the managers answered in the affirmative to the following standards respectively: "The health service network guarantees access to the dental prosthesis laboratory service for the attached population" and "There is planning of the supply of ophthalmologist services of the FHS, based on studies of demand". For the Work Management subdimension, the percentages of managers compliant with the standards varied from $22 \%$ to $74 \%$. The standards " $\mathrm{Mu}-$ nicipal health management has institutionalized career plans, jobsand salaries regarding Family Health" (22\%) and "Municipal management has an incentive program for the FHS, relating to the performance, compliance with goals and results achieved" (26\%) had the lowest percentage of compliant features. In the Strengthening of Coordination subdimension, there was a variation from $34 \%$ to $90 \%$ in the percentages of affirma- tive answers to the standards, with the lowest values obtained for the standards: "Municipal health management and/or the coordination establish or use mechanisms for the monitoring of the degree of satisfaction of users of FH" (34\%), "There is decentralized coordination, responsible for the monitoring of at most eight FHS" (38\%) and "The coordination of Basic Healthcare (BH)/ $\mathrm{FH}$ supports and promotes the training of Local Health Councils in the BHUs" (38\%) (Table 3).

In the Planning and Integration subdimension, from $27.1 \%$ to $89.6 \%$ of FHS coordinators replied in the affirmative to the standards. There was a lower percentage of affirmative answers to the following standards: "Municipal experiences with family health are presented at congresses and meetings in the area" $(27.1 \%)$ and "The coordination of the $\mathrm{BHC} / \mathrm{FH}$ is developing integration and partnership initiatives with academic institutions, permitting scientific output in the field of the BHC" $(27.1 \%)$. The majority of the municipalities answered in the affirmative to the standards of the subdimension "Support for Teams" (68.8\% to $91.7 \%)$. For the "Permanent Education Management" subdimension, the percentages of affirmative answers varied from $39.6 \%$ to $75 \%$. Two standards showed non-compliance for a higher percentage of coordinators: "Theo- 
Table 3. Frequency of municipalities with positive replies to the AMQ standard for the Development dimension of the Family Health Strategy $(n=50)$.

\begin{tabular}{|c|c|c|c|}
\hline Subdimension & Standards & $\begin{array}{l}\text { Municipalities } \\
\text { with positive } \\
\text { replies }\end{array}$ & $\begin{array}{c}\% \text { of } \\
\text { municipalities }\end{array}$ \\
\hline \multirow{19}{*}{$\begin{array}{l}\text { Installation/ } \\
\text { Implementation } \\
\text { of FH in the } \\
\text { municipality }\end{array}$} & $\begin{array}{l}\text { The Municipal Health Plan defines FH as a strategy for } \\
\text { the reorganization of Basic Care }\end{array}$ & 49 & 98 \\
\hline & $\begin{array}{l}\text { The installation of FHS gives priority to the areas with } \\
\text { less favorable socio-economic and health conditions and/ } \\
\text { or of social exclusion }\end{array}$ & 49 & 98 \\
\hline & $\begin{array}{l}\text { All of the teams are responsible for an attached } \\
\text { population of up to } 4,000 \text { individuals }\end{array}$ & 39 & 78 \\
\hline & $\begin{array}{l}\text { Municipal health management supplies the Information } \\
\text { Systems on a regular basis and within the established } \\
\text { deadlines }\end{array}$ & 48 & 96 \\
\hline & Municipal health management establishes $\mathrm{OH}$ teams & 50 & 100 \\
\hline & $\begin{array}{l}\text { The Municipal Health Plan details the guidelines and } \\
\text { planning for the installation, implementation and } \\
\text { consolidation of the FH }\end{array}$ & 47 & 94 \\
\hline & $\begin{array}{l}\text { Municipal health management carries out an analysis } \\
\text { of the health situation of the municipality in order to } \\
\text { support the installation of the FH }\end{array}$ & 35 & 70 \\
\hline & $\begin{array}{l}\text { The Municipal Health Secretariat maintains strategies for } \\
\text { awareness raising and dissemination of FH among the } \\
\text { population }\end{array}$ & 44 & 88 \\
\hline & $\begin{array}{l}\text { The directives and planning for the installation, } \\
\text { implementation and consolidation of FH are agreed and } \\
\text { approved with the CMS }\end{array}$ & 50 & 100 \\
\hline & $\begin{array}{l}\text { Municipal health management maintains analysis } \\
\text { and monitoring of the health situation to support the } \\
\text { implementation of FH }\end{array}$ & 41 & 82 \\
\hline & $\begin{array}{l}\text { The Municipal Health Secretariat maintains strategies } \\
\text { for awareness raising and dissemination of FH among } \\
\text { healthcare professionals of the municipal network }\end{array}$ & 45 & 90 \\
\hline & $\begin{array}{l}\text { Municipal health management develops actions in a form } \\
\text { of articulated with other government sectors }\end{array}$ & 45 & 90 \\
\hline & $\begin{array}{l}\text { Municipal health management develops the FH strategy, } \\
\text { installing OH in a proportion of at least one team for } \\
\text { every two FHS }\end{array}$ & 43 & 86 \\
\hline & $\begin{array}{l}\text { The municipal management monitors supply and } \\
\text { shortages of inputs in the FHU }\end{array}$ & 43 & 86 \\
\hline & $\begin{array}{l}\text { Municipal health management supports and legitimates } \\
\text { popular participation and social control for FH }\end{array}$ & 44 & 88 \\
\hline & $\begin{array}{l}\text { FH strategy is institutionalized within the municipality } \\
\text { through a legal instrument }\end{array}$ & 31 & 62 \\
\hline & $\begin{array}{l}\text { The organization of the teams in the UFH balances } \\
\text { criteria of regionalization, comfort and sanitary safety for } \\
\text { the development of activities }\end{array}$ & 43 & 86 \\
\hline & $\begin{array}{l}\text { The municipal health manager has agreements and/ } \\
\text { or partnerships formalized with organizations of civil } \\
\text { society and/or social movements }\end{array}$ & 21 & 42 \\
\hline & $\begin{array}{l}\text { The municipal management develops the FH installing } \\
\text { Oral Health in the proportion of one team for each FHS }\end{array}$ & 37 & 74 \\
\hline
\end{tabular}


Table 3. continuation

\begin{tabular}{|c|c|c|c|}
\hline Subdimension & Standards & $\begin{array}{l}\text { Municipalities } \\
\text { with positive } \\
\text { replies }\end{array}$ & $\begin{array}{c}\% \text { of } \\
\text { municipalities }\end{array}$ \\
\hline \multirow{19}{*}{$\begin{array}{l}\text { Integration } \\
\text { of the Service } \\
\text { Network }\end{array}$} & $\begin{array}{l}\text { Municipal health management expands and/or makes } \\
\text { adaptations to the service network as a function of the } \\
\text { installation of FH within the municipality }\end{array}$ & 45 & 90 \\
\hline & $\begin{array}{l}\text { Municipal health management expands and/or makes } \\
\text { adaptations to the network of references, basing itself on } \\
\text { studies of the demand verified and/or estimated in the FHS }\end{array}$ & 36 & 72 \\
\hline & $\begin{array}{l}\text { Planning exists for the supply of basic complimentary } \\
\text { examinations for the FHS }\end{array}$ & 45 & 90 \\
\hline & $\begin{array}{l}\text { Municipal health management guarantees the collection and } \\
\text { submission of all serology requests for diagnosing dengue } \\
\text { fever }\end{array}$ & 47 & 94 \\
\hline & $\begin{array}{l}\text { Municipal health management develops strategies for } \\
\text { ensuring a reference for the population attached to the FH } \\
\text { teams for hospitalizations in the basic clinics }\end{array}$ & 48 & 96 \\
\hline & $\begin{array}{l}\text { Municipal health management guarantees the execution of } \\
\text { high-risk prenatal tests for all referred pregnant women }\end{array}$ & 46 & 92 \\
\hline & $\begin{array}{l}\text { Planning exists for the supply of cardiology treatment for } \\
\text { the FHS based on studies of demand }\end{array}$ & 29 & 58 \\
\hline & $\begin{array}{l}\text { Planning exists for the supply of orthopedic treatment for } \\
\text { the FHS based on studies of demand }\end{array}$ & 30 & 60 \\
\hline & $\begin{array}{l}\text { The procedures of fixing tests, procedures and } \\
\text { hospitalizations are carried out by a reservation center }\end{array}$ & 42 & 84 \\
\hline & $\begin{array}{l}\text { The municipal health manager monitors and specialized } \\
\text { tests, requested by the FHS, which are not provided by the } \\
\text { reference }\end{array}$ & 41 & 82 \\
\hline & $\begin{array}{l}\text { Planning of the supply of rehabilitation services for the FHS } \\
\text { based on studies of demand }\end{array}$ & 33 & 66 \\
\hline & $\begin{array}{l}\text { Planning of the supply of ophthalmologist services for the } \\
\text { FHS based on studies of demand }\end{array}$ & 24 & 48 \\
\hline & $\begin{array}{l}\text { Planning of the supply of a nose and throat treatment for } \\
\text { the FHS based on studies of demand }\end{array}$ & 26 & 52 \\
\hline & $\begin{array}{l}\text { Planning of the supply of neurology treatment for the FHS } \\
\text { based on studies of demand }\end{array}$ & 26 & 52 \\
\hline & $\begin{array}{l}\text { Municipal health management develops strategies for } \\
\text { ensuring a reference for the population attached to the FH } \\
\text { teams for dentistry specialties }\end{array}$ & 30 & 60 \\
\hline & $\begin{array}{l}\text { The health services network guarantees access to the dental } \\
\text { prosthesis laboratory for the population attached to the } \mathrm{FH} \\
\text { teams }\end{array}$ & 15 & 30 \\
\hline & $\begin{array}{l}\text { Municipal health management develops integration } \\
\text { strategies between the mental health service and the FHS }\end{array}$ & 36 & 72 \\
\hline & $\begin{array}{l}\text { Municipal health management monitors the use of urgent, } \\
\text { emergency and first aid services of the public network for } \\
\text { the population covered by the FH }\end{array}$ & 35 & 70 \\
\hline & $\begin{array}{l}\text { Support by other network professionals for the FH teams is } \\
\text { provided systematically, on the basis of an established model }\end{array}$ & 41 & 82 \\
\hline
\end{tabular}

retical and practical training is offered in the basic areas for those higher-level FH professionals who require it" (39.6\%) and "The coordination of the $\mathrm{BH} / \mathrm{FH}$ permits specializationin the area for FHS professionals" (39.6\%). For the subdimension "Management of Assessment" (41.7\% to $91.7 \%$ ), only two standards received affirmative answers from less than $50 \%$ of the coordinators: 
Table 3. continuation

\begin{tabular}{|c|c|c|c|}
\hline Subdimension & Standards & $\begin{array}{l}\text { Municipalities } \\
\text { with positive } \\
\text { replies }\end{array}$ & $\begin{array}{c}\% \text { of } \\
\text { municipalities }\end{array}$ \\
\hline & $\begin{array}{l}\text { Municipal health management develops strategies for } \\
\text { ensuring that labor rights do not become precarious in the } \mathrm{FH}\end{array}$ & 16 & 32 \\
\hline & $\begin{array}{l}\text { The criteria of the SMS for the selection and recruitment of } \\
\text { FH professionals are described in an official document }\end{array}$ & 37 & 74 \\
\hline & $\begin{array}{l}\text { The criteria for selecting professionals for higher-level FH } \\
\text { give value to Residential or Postgraduate Studies in Family } \\
\text { Health }\end{array}$ & 18 & 36 \\
\hline & $\begin{array}{l}\text { The entry of high-level FH professionals is realized through } \\
\text { a public competition to fill permanent positions or public } \\
\text { sector jobs }\end{array}$ & 17 & 34 \\
\hline \multirow[t]{6}{*}{$\begin{array}{l}\text { Work } \\
\text { Management }\end{array}$} & $\begin{array}{l}\text { The entry of mid-level FH professionals is realized through } \\
\text { a public competition to fill permanent positions or public } \\
\text { sector jobs }\end{array}$ & 28 & 56 \\
\hline & $\begin{array}{l}\text { Higher-level FH professionals have been working in the } \\
\text { municipality for more than two years }\end{array}$ & 30 & 60 \\
\hline & $\begin{array}{l}\text { The ACS have been working in the municipality for more } \\
\text { than two years }\end{array}$ & 33 & 66 \\
\hline & $\begin{array}{l}\text { The municipal management has an incentive program for } \\
\text { the FHS related to performance, meeting targets and results } \\
\text { achieved }\end{array}$ & 13 & 26 \\
\hline & $\begin{array}{l}\text { Municipal health management has institutionalized career } \\
\text { plans, positions and salaries regarding the } \mathrm{FH}\end{array}$ & 11 & 22 \\
\hline & $\begin{array}{l}80 \% \text { of higher-level professionals in the teams have specific } \\
\text { training in the area }\end{array}$ & 22 & 44 \\
\hline \multirow{12}{*}{$\begin{array}{l}\text { Strengthening } \\
\text { of Coordination }\end{array}$} & The SMS has a specific coordinating body for $\mathrm{BH} / \mathrm{FH}$ & 41 & 82 \\
\hline & $\begin{array}{l}\text { The coordinating body of the } \mathrm{BH} / \mathrm{FH} \text { is formally included } \\
\text { in the organizational structure of the Municipal Health } \\
\text { Secretariat }\end{array}$ & 32 & 64 \\
\hline & $\begin{array}{l}\text { Municipal health management involves the coordination of } \\
\text { the } \mathrm{BH} / \mathrm{FH} \text { in the process of agreeing on the } \mathrm{BH} \text { indicators in } \\
\text { the Health Pact }\end{array}$ & 45 & 90 \\
\hline & $\begin{array}{l}\text { Municipal management values the participation of the } \\
\text { coordinating body of the } \mathrm{BH} / \mathrm{FH} \text { in congresses and meetings } \\
\text { of the area }\end{array}$ & 43 & 86 \\
\hline & $\begin{array}{l}\text { The technician(s) responsible) for the coordination of the } \\
\mathrm{BH} / \mathrm{FH} \text { has/have specific training in the area }\end{array}$ & 31 & 62 \\
\hline & $\begin{array}{l}\text { The coordinating body of the } \mathrm{BH} / \mathrm{FH} \text { consists of a multi- } \\
\text { professional team for the support, supervision and technical } \\
\text { monitoring work of FHS }\end{array}$ & 25 & 50 \\
\hline & $\begin{array}{l}\text { Decentralized coordination exists, which is responsible for } \\
\text { the monitoring of at most } 8 \mathrm{FH} \text { teams }\end{array}$ & 19 & 38 \\
\hline & $\begin{array}{l}\text { The SMS has a professional coordinator of the } \mathrm{BH} / \mathrm{FH} \text {, } \\
\text { responsible for the area of } \mathrm{OH}\end{array}$ & 32 & 64 \\
\hline & $\begin{array}{l}\text { Municipal health management and/or the coordinating body } \\
\text { establish or use mechanisms for the monitoring of the degree } \\
\text { of satisfaction of the users of the FH }\end{array}$ & 17 & 34 \\
\hline & $\begin{array}{l}\text { Technical areas work in an integrated manner with the } \\
\text { coordination of the } \mathrm{BH} / \mathrm{FH}\end{array}$ & 42 & 84 \\
\hline & $\begin{array}{l}\text { The coordinating body of the } \mathrm{BH} / \mathrm{FH} \text { supports and promotes } \\
\text { the training of Local Health Councils in the basic units }\end{array}$ & 19 & 38 \\
\hline & $\begin{array}{l}\text { Municipal health management develops a Humanization } \\
\text { policy for the municipal network, in conjunction with the } \\
\text { BH/FH coordinating body and other technical areas of the } \\
\text { SMS, considering FH }\end{array}$ & 32 & 64 \\
\hline
\end{tabular}


"Are epidemiological surveys of Oral Healthcarried out in the municipality" (41.7\%) and "The coordination of the $\mathrm{BH} / \mathrm{FH}$ selects criteria and indicators for assessing with the teams the impact on the health conditions of the population" (45.8\%). In the "Standardization" subdimension, the percentages of coordinators with affirmative answers to the standardsvaried from $27.1 \%$ to $91.7 \%$, with the lowest value attributed to the standard "The coordination of the $\mathrm{BH} / \mathrm{FH}$ makes available protocols and technical information to the FHS/SB on the approach to urgent situations in Mental Health" (Table 4).

The percentage of the managers of the FHU who replied in the affirmative to the standards of the subdimension Infrastructure and Equipment of the FHU varied from $15.2 \%$ to $86.2 \%$. The standards with the lowest percentage of compliant replies were: "The FHU has equipment available indicated for first aid in urgent cases and emergencies" (15.2\%) and "The FHU has other equipment available for health care by the teams" $(17,6 \%)$. In the "Inputs, Immunobiologicals and Medicines" subdimension, the percentages of municipalities compliant with the standards varied from $48.1 \%$ to $92.4 \%$. The standard with the lowest compliance was: "The FHU has basic medicines available indicated for first aid for cases of grand mal epilepsy crises, in accordance with local protocols, which are stored in a suitable location" (48.1\%) (Table 5).

\section{Discussion}

In general, the managers, municipal coordinators of the FHS and FHU managers of the municipalities of the Northeast region of Minas Gerais assessed the quality of the FHS positively, as witnessed by the high average values of the compliance scores and of the percentages of affirmative answers to the standards. No studies were identified which had used the instruments directed towards management in other Brazilian regions, solely for FHS teams. For example, Montes Claros (Minas Gerais), the Team component of the AIQ was assessed by FHS professionals, with compliance scores exceeding 50\% in each of the subdimensions, except for three of them: Community Participation, Social Control and Adolescent Health ${ }^{7}$.

The limitations of the AIQ have been previously highlighted ${ }^{6,8,15,16}$. In the deployment of the AIQ, in the city of Registro (São Paulo), it was observed that its feasibility depended on the ef- forts of the managers and that healthcare professionals encountered difficulties in completing the questionnaires $^{8}$. The difficulties of analyzing the data generated by the tools was also highlighted, given that the methodology of the AIQ does not define $i^{15}$. Nor can it be stated that the replies obtained comply with the reality of practice, since direct observation techniques were not used ${ }^{16,17}$. The possibility of overestimation of the scores obtained by the AIQ is still subject to debate, since the reply standards are dichotomous and a perception of inefficiency on the part of the team may be generated by a high number of negative replies ${ }^{16}$.

In this study, we chose to obtain the sum of the compliance scores for each assessed dimension/subdimension, without considering the quality stages of the standards, with a methodology similar to that previously realised $d^{7,8,17,18}$. This choice was made and the study then identified the non-linearity of the relationship between the quality stages of the AIQ and the complexity of deployment of the work processes recommended by the quality standards ${ }^{6}$. One of the difficulties encountered in this study was the return of completed questionnaires, which did not reach $100 \%$ of replies for any of the three tools. The lowest rate of response $(76.2 \%)$ was among the FHS coordinators, which may be explained by the absence of a specific function in municipalities with up to three FHS. For the tool targeted at the managers of the FHU, there was a loss of $100 \%$ in eight municipalities under the jurisdiction of the GRS of Pedra Azul. This loss may be due to the difficulties faced by the managers in distributing and requesting the participation of the FHU managers and the poor efforts made by them in replying to the question and delivered by the manager. The loss of these data did not compromise the results of the survey, since the reality of health management in the municipalities which did not take part in the study is identified with the others with the same level of population.

The results revealed that the FHS were favorably assessed by the managers regarding the dimension Development of the FHS, in particular for the subdimension Deployment/Implementation, which characterizes the political and institutional definition of the FHS as a model of care dispensed to the population. At the same time, the study showed that many of the municipalities still needed to establish formal partnerships/ agreements with the organizations of civil society and/or social movements. This need was also highlighted by Sarti et al. ${ }^{17}$, when only $8.5 \%$ of 
Table 4. Frequency of municipalities with positive replies to the standards of the AMQ for the dimension Technical Coordination of Teams $(n=48)$.

\begin{tabular}{|c|c|c|c|}
\hline Subdimension & Standard & n & $\begin{array}{c}\% \\
\text { municípios }\end{array}$ \\
\hline \multirow[t]{8}{*}{$\begin{array}{l}\text { Planning and } \\
\text { Integration }\end{array}$} & $\begin{array}{l}\text { The coordinating body of the } \mathrm{BH} / \mathrm{FH} \text { has a timetable of visits to the UFH and } \\
\text { meetings with the FHS }\end{array}$ & 43 & 89.6 \\
\hline & $\begin{array}{l}\text { The coordinating body of the } \mathrm{BH} / \mathrm{FH} \text { has a work plan which guides the } \\
\text { activities to be developed }\end{array}$ & 30 & 62.5 \\
\hline & $\begin{array}{l}\text { The coordinating body of the } \mathrm{BH} / \mathrm{FH} \text { registers the monitoring of the } \\
\text { situation of } \mathrm{FH} \text { in the municipality, the number of teams, coverage, } \\
\text { professionals and results }\end{array}$ & 46 & 95.8 \\
\hline & $\begin{array}{l}\text { The coordinating body of the } \mathrm{BH} / \mathrm{FH} \text { takes part regularly in the meetings of } \\
\text { the Municipal Health Council }\end{array}$ & 39 & 81.3 \\
\hline & $\begin{array}{l}\text { The coordinating body of the } \mathrm{BH} / \mathrm{FH} \text { meets with the public and social sectors } \\
\text { of the municipality }\end{array}$ & 35 & 72.9 \\
\hline & $\begin{array}{l}\text { The coordinating body of the } \mathrm{BH} / \mathrm{FH} \text { possesses and makes available to the } \\
\text { FHS an updated register of the social resources of the municipality }\end{array}$ & 21 & 43.8 \\
\hline & $\begin{array}{l}\text { The municipal experiences with FH are presented at congresses and meetings } \\
\text { in the area }\end{array}$ & 13 & 27.1 \\
\hline & $\begin{array}{l}\text { The coordinating body of the BH/FH develops initiatives for integration and } \\
\text { partnership with academic institutions, making possible the realization of } \\
\text { scientific production in the field of Basic Health Care }\end{array}$ & 13 & 27.1 \\
\hline \multirow{7}{*}{$\begin{array}{l}\text { Monitoring of } \\
\text { the Teams }\end{array}$} & The coordinating body of the BH/FH meets on a monthly basis with the FHS & 44 & 91.7 \\
\hline & $\begin{array}{l}\text { The coordinating body of the BH/FH guarantees a weekly shift to the FHS } \\
\text { intended for a team meeting }\end{array}$ & 34 & 70.8 \\
\hline & $\begin{array}{l}\text { The coordinating body of the } \mathrm{BH} / \mathrm{FH} \text { uses instruments to monitor the } \\
\text { actions and practices of the } \mathrm{FH}\end{array}$ & 33 & 68.8 \\
\hline & $\begin{array}{l}\text { The coordinating body of the BH/FH develops strategies for administering } \\
\text { conflicts between FH professionals }\end{array}$ & 40 & 83.3 \\
\hline & $\begin{array}{l}\text { The coordinating body of the } \mathrm{BH} / \mathrm{FH} \text { assesses the level of satisfaction of } \\
\text { professionals with their work, taking into consideration criticisms and } \\
\text { suggestions for planning actions }\end{array}$ & 33 & 68.8 \\
\hline & $\begin{array}{l}\text { The coordinating body of the } \mathrm{BH} / \mathrm{FH} \text { develops strategies with the teams for } \\
\text { confronting problems encountered while providing care to the population }\end{array}$ & 43 & 89.6 \\
\hline & $\begin{array}{l}\text { The coordinating body of the } \mathrm{BH} / \mathrm{FH} \text { develops instruments for the } \\
\text { organization and monitoring of FHS actions and practices in conjunction } \\
\text { with the teams }\end{array}$ & 37 & 77.1 \\
\hline $\begin{array}{l}\text { Management } \\
\text { of Permanent }\end{array}$ & $\begin{array}{l}\text { The coordinating body of the } \mathrm{BH} / \mathrm{FH} \text { ensures preparatory courses for } \mathrm{FH} \\
\text { workers }\end{array}$ & 34 & 70.8 \\
\hline \multirow[t]{5}{*}{ Education } & $\begin{array}{l}\text { The coordinating body of the } \mathrm{BH} / \mathrm{FH} \text { takes part regularly and forums or } \\
\text { meetings for the Development of the Permanent Education }\end{array}$ & 36 & 75.0 \\
\hline & $\begin{array}{l}\text { The coordinating body of the } \mathrm{BH} / \mathrm{FH} \text { decides, together with the FHS on the } \\
\text { themes and activities to be developed in Permanent Education }\end{array}$ & 34 & 70.8 \\
\hline & $\begin{array}{l}\text { Theoretical and practical training is offered in basic areas for those } \\
\text { higher-level FH professionals who require it }\end{array}$ & 19 & 39.6 \\
\hline & $\begin{array}{l}\text { Technical areas and FH develop Permanent Education activities in integrated } \\
\text { fashion }\end{array}$ & 28 & 58.3 \\
\hline & $\begin{array}{l}\text { The coordinating body of the } \mathrm{BH} / \mathrm{FH} \text { ensures the execution of specializations } \\
\text { in the area for FHS professionals }\end{array}$ & 19 & 39.6 \\
\hline
\end{tabular}

the FHS in their sample included representatives of social movements in their planning of actions. These partnerships will be able to establish ar- ticulated actions between the municipal health management and the works already developed by entities of civil society, in such a way as to favor 
Table 4. continuation

\begin{tabular}{|c|c|c|c|}
\hline Subdimension & Standard & $\mathbf{n}$ & $\begin{array}{c}\% \\
\text { municipalities }\end{array}$ \\
\hline Management of & The coordination evaluates the output of FHS on a monthly basis & 42 & 87.5 \\
\hline \multirow[t]{9}{*}{ Assessment } & $\begin{array}{l}\text { The coordinating body of the } \mathrm{BH} / \mathrm{FH} \text { uses the information of } \\
\text { the SIAB as a management instrument: assessment, planning and } \\
\text { monitoring }\end{array}$ & 43 & 89.6 \\
\hline & $\begin{array}{l}\text { The coordinating body of the } \mathrm{BH} / \mathrm{FH} \text { analyses the reports of the SIAB } \\
\text { on a monthly basis, in conjunction with the FHS }\end{array}$ & 28 & 58.3 \\
\hline & $\begin{array}{l}\text { The coordinating body of the } \mathrm{BH} / \mathrm{FH} \text { analyses data and reports of the } \\
\text { SUS or health information system }\end{array}$ & 35 & 72.9 \\
\hline & $\begin{array}{l}\text { The coordinating body of the } \mathrm{BH} / \mathrm{FH} \text { chooses criteria and indicators } \\
\text { for evaluating with the teams the impact on the health conditions of } \\
\text { the population }\end{array}$ & 22 & 45.8 \\
\hline & $\begin{array}{l}\text { The coordinating body analyses the demand for FH tests and referrals, } \\
\text { observing whether there is a match with the estimated requirement }\end{array}$ & 27 & 56.3 \\
\hline & $\begin{array}{l}\text { The coordinating body of the } \mathrm{BH} / \mathrm{FH} \text { debates the results and plans the } \\
\text { objectives of FH with the teams }\end{array}$ & 38 & 79.2 \\
\hline & $\begin{array}{l}\text { The coordinating body of the } \mathrm{BH} / \mathrm{FH} \text { meets with the other areas of } \\
\text { the SMS to discuss the results achieved in } \mathrm{BH} \text {. }\end{array}$ & 26 & 54.2 \\
\hline & $\begin{array}{l}\text { The coordinating body of the } \mathrm{BH} / \mathrm{FH} \text { evaluates the established goals } \\
\text { for the Basic Healthcare indicators of the Health Pact with the FHS }\end{array}$ & 44 & 91.7 \\
\hline & $\begin{array}{l}\text { Epidemiological surveys of Oral Health are carried out within the } \\
\text { municipality }\end{array}$ & 20 & 41.7 \\
\hline \multirow[t]{9}{*}{ Standardization } & $\begin{array}{l}\text { The coordinating body of the } \mathrm{BH} / \mathrm{FH} \text { makes documents available to } \\
\text { all of the FHS with the principles and guidelines of the FH strategy }\end{array}$ & 32 & 66.7 \\
\hline & $\begin{array}{l}\text { The coordinating body of the } \mathrm{BH} / \mathrm{FH} \text { uses a written standard with } \\
\text { regard to the physical installation and equipment }\end{array}$ & 28 & 58.3 \\
\hline & $\begin{array}{l}\text { The } \mathrm{BH} / \mathrm{FH} \text { coordinating body makes updated information from the } \\
\text { municipal reference and counter-reference system available to all of } \\
\text { FHS units }\end{array}$ & 32 & 66.7 \\
\hline & $\begin{array}{l}\text { The coordinating body of the } \mathrm{BH} / \mathrm{FH} \text { provides a manual of basic } \\
\text { pharmacy medicines }\end{array}$ & 35 & 72.9 \\
\hline & $\begin{array}{l}\text { The coordinating body of the } \mathrm{BH} / \mathrm{FH} \text { makes supporting technical- } \\
\text { scientific material available to the teams on frequent situations in } \\
\text { Basic Health Care }\end{array}$ & 37 & 77.1 \\
\hline & $\begin{array}{l}\text { The coordinating body of the BH/FH makes supporting technical- } \\
\text { scientific material available to the teams on the most prevalent } \\
\text { infectious and parasitic diseases in the country. }\end{array}$ & 44 & 91.7 \\
\hline & $\begin{array}{l}\text { The coordinating body of the } \mathrm{BH} / \mathrm{FH} \text { has documentation establishing } \\
\text { the action of each FH professional }\end{array}$ & 31 & 64.6 \\
\hline & $\begin{array}{l}\text { The coordinating body of the } \mathrm{BH} / \mathrm{FH} \text { provides protocols and technical } \\
\text { information to the } \mathrm{FHS} / \mathrm{OH} \text { on dealing with urgent situations }\end{array}$ & 21 & 43.8 \\
\hline & $\begin{array}{l}\text { The coordinating body of the } \mathrm{BH} / \mathrm{FH} \text { provides protocols and technical } \\
\text { information to the FHS/OH on dealing with urgent situations in } \\
\text { Mental Health }\end{array}$ & 13 & 27.1 \\
\hline
\end{tabular}

an improvement in the quality of life of municipal residents ${ }^{19}$.

The worst result obtained in the Development of the FHS dimension was attributed to the Work Management subdimension. The need was detected to develop FHS professionals, since more than $70 \%$ of the municipalities were not compliantwith standards which they confirmed regarding Plans for Positions, Careers and Salaries (PCCS) and worker incentive programs. This question has already been discussed, with public policies elaborated, such as the proposal of PCCS approved at the $14^{\text {th }}$ National Health Conference $^{20}$. Such policies are important as sets 
Table 5. Frequency of teams with positive replies to the AMQ standard for the Family Health Unit dimension $(\mathrm{n}=210)$.

\begin{tabular}{|c|c|c|c|}
\hline Subdimension & Standard & $\mathbf{n}$ & $\begin{array}{c}\% \\
\text { Teams }\end{array}$ \\
\hline FHU & Each FHS has a clinic with basic equipment for attending its population & 174 & 82.9 \\
\hline Infrastructure & The UFH clinics permit the visual and auditory privacy of health care & 181 & 86.2 \\
\hline \multirow[t]{22}{*}{ and Equipment } & $\begin{array}{l}\text { Clinics where gynecological examinations are carried out have, as a } \\
\text { minimum, screens for dressing and undressing }\end{array}$ & 179 & 85.2 \\
\hline & The ACS have basic equipment for external work & 113 & 53.8 \\
\hline & $\begin{array}{l}\text { The FHS have complete equipment and orthodontic equipment for the } \\
\text { regular performance of its activities }\end{array}$ & 146 & 69.5 \\
\hline & $\begin{array}{l}\text { Considering the physical installation, all areas of the UFH have adequate } \\
\text { conditions for carrying out basic health actions }\end{array}$ & 118 & 56.2 \\
\hline & $\begin{array}{l}\text { The UFH has a covered space, exclusively for reception and waiting, with } \\
\text { a number of seats compatible with the expected demand }\end{array}$ & 164 & 78.1 \\
\hline & $\begin{array}{l}\text { The UFH has an exclusive refrigerator for vaccines with temperature } \\
\text { control for the preservation of immunobiologicals }\end{array}$ & 118 & 56.2 \\
\hline & $\begin{array}{l}\text { The UFH plans the use and adaptation of environments for applying } \\
\text { bandages, inhalation, sutures and the observation of patients }\end{array}$ & 146 & 69.5 \\
\hline & $\begin{array}{l}\text { There are sufficient quantities of gynecological-obstetric equipment for } \\
\text { the work of the FHS }\end{array}$ & 169 & 80.5 \\
\hline & $\begin{array}{l}\text { The number of clinics of the UFH allows doctors and nurses to provide } \\
\text { outpatient FH treatment at the same time }\end{array}$ & 172 & 81.9 \\
\hline & $\begin{array}{l}\text { The tensiometers and scales of the UFH are measured in accordance } \\
\text { with technical parameters }\end{array}$ & 81 & 38.6 \\
\hline & The ACS have other items of equipment for external work & 56 & 26.7 \\
\hline & The UFH has a telephone line & 65 & 31.0 \\
\hline & The UFH has computer equipment & 97 & 46.2 \\
\hline & $\begin{array}{l}\text { The UFH has a room for holding team meetings, internal activities of } \\
\text { the ACS and Permanent Education activities }\end{array}$ & 110 & 52.4 \\
\hline & The UFH has other items of equipment for treatment by the teams & 37 & 17.6 \\
\hline & $\begin{array}{l}\text { The UFH has equipment recommended for first aid in urgent and } \\
\text { emergency cases }\end{array}$ & 32 & 15.2 \\
\hline & $\begin{array}{l}\text { Travel by the FH professionals to carry out planned external activities is } \\
\text { carried out in a SMS vehicle }\end{array}$ & 162 & 77.1 \\
\hline & The UFH has electronic equipment for educational activities & 105 & 50.0 \\
\hline & $\begin{array}{l}\text { The dentistry clinics allow the provision of DHT treatment and dental } \\
\text { surgery in an integrated manner }\end{array}$ & 93 & 44.3 \\
\hline & $\begin{array}{l}\text { The UFH is equipped to treat individuals with special needs: ramps, } \\
\text { banisters, width of the doors, restrooms and wheelchairs }\end{array}$ & 76 & 36.2 \\
\hline & $\begin{array}{l}\text { The UFH has access to the Internet and makes it available to FH workers } \\
\text { on the basis of defined criteria }\end{array}$ & 53 & 25.2 \\
\hline & Clinics where gynecological examinations are carried out have their own & 148 & 70.5 \\
\hline
\end{tabular}

it continues

of incentives and strategies for the gradual incorporation of management functions by federated entities ${ }^{21}$. At the same time, in the Northeast macroregion, the elaboration of local work management policies has received little discussion at the meetings of the microregional CIBs. Analyzing the consolidation agreements realized by the CIB-SUS/MG, we may observe the discussion on great demand for the accreditation of newteams, the shutting down of units, the qualification for the provision of certain clinical services, the approval of documents; with questions relating to human resources little discussed at these meetings $^{22}$. This demand must be encouraged, for the construction of joint solutions and new proposals regarding work management, not only in the Northeast region, but in the whole of the state of Minas Gerais. 
Table 5. continuation

\begin{tabular}{|c|c|c|c|}
\hline Subdimension & Standard & n & $\begin{array}{c}\% \\
\text { Teams }\end{array}$ \\
\hline \multirow{16}{*}{$\begin{array}{l}\text { Inputs, } \\
\text { Imunobiologicals } \\
\text { and Medicines }\end{array}$} & The UFH provides all of the vaccines for the basic calendar of the & 162 & 77.1 \\
\hline & $\begin{array}{l}\text { The UFH provides on a regular basis and in sufficient quantities the } \\
\text { basic medicines prescribed for the treatment of the most frequent } \\
\text { parasitic infections }\end{array}$ & 174 & 82.9 \\
\hline & $\begin{array}{l}\text { The FHS/OH have materials and inputs for carrying out educational } \\
\text { activities with the population }\end{array}$ & 160 & 76.2 \\
\hline & $\begin{array}{l}\text { The UFH regularly dispenses medicines indicated for the prevention } \\
\text { and treatment of deficiency anemias and hipovitaminoses in } \\
\text { sufficient quantities }\end{array}$ & 179 & 85.2 \\
\hline & $\begin{array}{l}\text { The UFH has basic inputs in sufficient quantities for the regular } \\
\text { performance of health actions }\end{array}$ & 194 & 92.4 \\
\hline & $\begin{array}{l}\text { The UFH has } \mathrm{OH} \text { inputs in sufficient quantities for the regular } \\
\text { performance of health actions }\end{array}$ & 157 & 74.8 \\
\hline & $\begin{array}{l}\text { The UFH has printed material in sufficient quantities for the regular } \\
\text { performance of health actions }\end{array}$ & 194 & 92.4 \\
\hline & The UFH has glucometers and supplies tapes in sufficient quantities & 159 & 75.7 \\
\hline & $\begin{array}{l}\text { The UFH regularly dispenses basic antibiotics indicated for the } \\
\text { treatment of the most prevalent infectious diseases in sufficient } \\
\text { quantities, with these appearing in the standardized list of antibiotics } \\
\text { of the SMS }\end{array}$ & 165 & 78.6 \\
\hline & $\begin{array}{l}\text { The UFH regularly dispenses sufficient quantities of the basic } \\
\text { medicines indicated for the treatment of Systemic Arterial } \\
\text { Hypertension }\end{array}$ & 176 & 83.8 \\
\hline & $\begin{array}{l}\text { The UFH regularly dispenses regularly dispenses sufficient quantities } \\
\text { of the basic oral medicines indicated for the treatment of Diabetes } \\
\text { Mellitus }\end{array}$ & 178 & 84.8 \\
\hline & $\begin{array}{l}\text { The UFH regularly dispenses NPH insulin indicated for the } \\
\text { treatment of diabetes mellitus in sufficient quantities, deriving from } \\
\text { adequate storage in a refrigerator }\end{array}$ & 157 & 74.8 \\
\hline & $\begin{array}{l}\text { The UFH has basic medicines indicated for first aid for cases of } \\
\text { hypertensive crisis, in accordance with local protocols, with these } \\
\text { stored under adequate conditions }\end{array}$ & 152 & 72.4 \\
\hline & $\begin{array}{l}\text { The UFH has inhalatory medicines for asthma attacks, stored in an } \\
\text { adequate location }\end{array}$ & 151 & 71.9 \\
\hline & $\begin{array}{l}\text { The UFH has medicines for the treatment of diseases of the } \\
\text { gastrointestinal tract }\end{array}$ & 139 & 66.2 \\
\hline & $\begin{array}{l}\text { The UFH has basic medicines indicated for first aid for cases of } \\
\text { grand mal epilepsy crises, in accordance with local protocols, with } \\
\text { these stored under adequate conditions }\end{array}$ & 101 & 48.1 \\
\hline
\end{tabular}

Problems in the area of Work Management within the SUS were listed in the study by the Institute of Social Medicine of the UERJ ${ }^{23}$. Regarding management strictly speaking, state managers highlighted the inadequate remuneration ofworkers, increasing work and security, the limits of the Law of Fiscal Responsibility, government insensitivity to the sector, the absence of the PCCS, the absence of planning and the absence of competitions as the principal challenges re- lating to the execution of a satisfactory policy in the field of work management within the SUS ${ }^{23}$. These results are similar to those encountered in this survey, which highlight that precarious labor rights, the depreciation of the qualifications of professionals, the absence of public competitions for entry into the health services, the abstaining of the municipality from incentivizing teams which meet established targets and the absence of the PCCS are the major problems in the Work 
Management subdimension assessed by the AIQ.

Strengthening of Coordination obtained the second lowest assessment within the Development of the FHS dimension, demonstrating the absence of monitoring of satisfaction of the user of the FHS in many municipalities. Verifying the opinion of users of the work developed by the FHS is an important form of assessment for prioritizing management actions with the focus on improving care, as well as in promoting popular participation and social control. Assessing the perception of the user with regard to the degree of satisfaction with the care provided by the FHS may contribute to "[...] guaranteeing that the improvements in the services are concentrated on what users want, in opposition to what decision-makers think that they want"24.

Another critical point of the Strengthening of Coordination subdimension was the absence of support for the training local health councils in the UBS. The FHS has in its work methodology the incentivizing of social participation, aiming to contribute to the reorganization of work practices on the basis of the $\mathrm{PHC}^{25}$. Local health councils are privileged tools for enforcing civic rights $^{26}$, as spaces which promote the creativity of users in proposing and collaborating local health policy. Incentivizing social participation, supporting and guaranteeing the training of the local health councils is the role of the manager. Such councils may extend community participation in inspection, proposal, execution, monitoring and support $^{27}$ for public health policies ${ }^{1}$, facilitating the integration of ideas which reconcile the interests of service providers, workers and healthcare professionals, public managers and representatives of popular and union movements ${ }^{28}$.

There was less compliance with the standards of the "Strengthening of Coordination" subdimension and specifically with the standard relating to the existence of decentralized coordination, responsible for support of at most eight FHS teams. In municipalities with a lower population, this is attributed to the fact that some municipalities of the Northeast macroregion of Minas Gerais do not possess a FHS coordinator, with this function assumed by themanagers themselves or by a professional who carries out works relating to the local administration of health or by a FHS professional, generally the nurse. This fact generates an overload of work, diversion of functions and the failure to execute or partial execution of the attributes relating to the municipal coordinator of the FHS. The correlation encountered is nevertheless in accor- dance with decision 340/2007 of the CIB-MG, which determines that municipalities with three or more deployed teams must have a municipal coordinating body responsible for $\mathrm{FHS}^{29}$ and in many municipalities, three or fewer FHS were observed. It is also possible to highlight that in the municipalities where there is involvement and articulation of advisers, supervisors, coordinators and the health secretary in management, there is a change of conduct in the management work with the purpose of organizing and qualifying $\mathrm{FH}^{30}$.

The assessment of the Technical Coordination dimension of the FHS highlighted in two subdimensions the unequal access to educational processes among the municipalities, with a high percentage of the coordinators replying negatively to questions on the feasibility of theoretical and practical training and of specialization for FHS workers. One of the foundations of the PHC is the development of healthcare professionals, through encouragement and constant monitoring of their training and capacity building ${ }^{31}$. On the other hand, we highlight educational actions, such as capacity building on specific issues, directed towards healthcare professionals, which take place in accordance with the need/interest identified by the manager, as well as planned actions introduced by the MoH. Figueiredo et al. observed that permanent education actions relating to health management itself are not carried out, with such actions not even cited in municipalities with less than 10,000 inhabitants $^{30}$. The functions and actions relating to planning and health management are basic premises of the FHS and the poor performance of these functions observed in the set of municipalities, both in this study and in others ${ }^{17,30}$, indicates the need to assess the process of permanent education of the teams and the priority attributed to it by the managers ${ }^{17}$.

Another item with a negative assessment by the majority of the municipalities showed that joint activities with academic institutions are still in the very early stages. Larger municipalities have a growing interaction with training centers, whether university or not, explaining the correlation observed between the compliance scores of the "Permanent Education Management" subdimension and the municipal population. The integration between teaching and service is the work of students and lecturers of the courses in the area of health with health team workers, including managers, aiming at the quality of individual and collective health care, the quality of 
professional training and to the development/ satisfaction of workers of the services ${ }^{32}$. Teaching-service co-operation relations tend to be concentrated only in those established between large municipalities and the training centers located within them. According to the Nacional Council of Health Secretaries, the state manager is responsible for permitting and mediating this access for smaller municipalities without training institutions within their territory ${ }^{33}$. The $\mathrm{MoH}$ has two initiatives which permit teaching-service integration, the Pró-saúde and the Telessaúde Brasil program, which provide opportunities for learning and assist with improving the development of practices in the area of health ${ }^{34,35}$.

The compliance scores were higher in municipalities with higher population for the subdimensions "Support for Teams", "Permanent Education Management" and "Standardization of the Technical Coordination of Teams Dimension". This correlation may be attributed to the presence of the coordinator in municipalities with a higher number of FHS. In Silva's view, "[...] the coordinators develop relevant management functions in a municipal context, both for the teams, and for the management [...] ${ }^{36}$. A previous study demonstrated that higher population coverage and longer deployment times did not necessarily indicate greater maturity in terms of organization of health services, but a higher probability of adjustment of the FHS to the quality standards of the $\mathrm{AIQ}^{17}$.

The study highlighted deficiencies in the Infrastructure and Equipment of the FHS of the Northeast region of Minas Gerais, with the compliance scores for this subdimension being lower than that of Inputs, Immunobiologicals and Medicines. On analyzing the replies to the standards, deficiencies were perceived with regard to the existence of equipment indicated for first aid in urgent and emergency cases and other items, which permitted care by the teams and consequently an increase in the resolvability of the PHC. This finding may be explained by the few investments allocated to the acquisition of equipment for the PHC, as well as by the historic character of the urgent and emergency care being provided exclusively in hospitals and specialized clinics. According to the CONASEMS, the BHUs which develop PHC actions require adequate physical installations, with the equipment and inputs necessary for the quality of the services provided $^{31}$. In this way, adequate and organized infrastructure and available and functioning equipment are fundamental for receiving users in a dignified and respectful manner, under salubrious and biologically safe conditions for health workers.

The smaller municipalities presented higher compliance for the standards of the subdimensions Infrastructure and Equipment of the FHU. This correlation may be attributed to two factors: a) standardization of the minimum criteria for physical structure and equipment of the BHUs, within the context of the state of Minas Gerais (SES Resolution No. 604/2004) 37 $^{37}$ b) transfer of financial resources by the state to the municipalities for investment in improving the infrastructure and quality of the PHC, with the smaller municipalities being the first to be considered with state resources for the construction and reform or expansion of BHUs (SES Resolution No. $760 / 2005)^{38}$.

The subdimension "Inputs, Immunobiologicals and Medicines" received a better assessment by the FHU managers in the municipalities with a lower HDI. This relationship may be explained by the financial incentives granted to small-scale municipalities; by the high rate of coverage of the FHS for free dispensing of medicines for $\mathrm{PHC}^{17}$ - Programa Farmácia de Minas [Minas Pharmacy Program]; as well as by the higher vaccination coverage in populations with higher FHS coverage, notably municipalities with a lower $\mathrm{HDI}^{39}$.

The use of the AIQ tools permitted the identification of the subdimensions requiring greater attention and more intervention by the municipal management. In addition to the descriptive analysis of the average scores of features compliant with the quality standards of the AIQ, the correlation with the population and with the municipal HDI permitted the identification of inequalities in the assessment pursuant to these indicators, allowing the establishment of priorities in the planning of actions. The percentage coverage of the population and the deployment time for the FHS were not significantly correlated with any dimension. This may have occurred as a function of the homogeneity among groups regarding these two variables, since in the majority of the municipalities, $100 \%$ coverage and more than 10 years of deployment of the FHS were observed. In order for the population of the Northeast of Minas to obtain benefits with the better performance of the FHS, management, political and financial encouragement for its PHC network is fundamental, with assessment a fundamental process for promoting this growth.

It may be concluded that self-assessmentof the quality of the FHS in the Northeast macrore- 
gion of Minas Gerais, within the context of the management, was generally positive. The worst assessment was observed in the subdimensions of "Work Management", "Permanent Education" and "Inputs, Immunobiologicals and Medicines". The larger the municipal population, the better the assessment by the managers in with regard to the "Strengthening of Coordination", "Support for Teams", "Permanent Education Management and Standardization" and the worse the assessment of "Infrastructure and Equipment".

\section{Collaborators}

AVL Cardoso, APN Chain, RIP Mendes, EF Ferreira, AMD Vargas, AMEB Lima and RC Ferreira also took part in all of the stages of elaboration of this article. 


\section{References}

1. Souza HM. O PSF como Indutor da Institucionalização da Avaliação na Atenção Básica. Rev Bras Saude Fam 2002; 6(2):10-15.

2. Bodstein R. Atenção básica na agenda da saúde. Cien Saude Colet 2002; 7(3):401-412.

3. Brasil. Ministério da Saúde (MS). Secretaria de Atenção à Saúde. Departamento de Atenção Básica. Coordenação de Acompanhamento e Avaliação. Avaliação da atenção básica em saúde: caminhos da institucionalização. Brasília: MS; 2005.

4. Brasil. Ministério da Saúde (MS). Avaliação para a melhoria da qualidade da Estratégia Saúde da Família. $3^{\mathrm{a}}$ ed. Brasília: MS; 2008.

5. Brasil. Ministério da Saúde (MS). Secretaria de Atenção à Saúde. Departamento de Atenção Básica. Programa Nacional de Melhoria do Acesso e da Qualidade da Atenção Básica (PMAQ): manual instrutivo. Brasília: MS; 2012.

6. Sarti TD, Maciel ELN, Campos CEA, Zandonade E, Ruschi GE. Validade de conteúdo da Avaliação para Melhoria da Qualidade da Estratégia Saúde da Família. Physis 2011; 21(3):865-878.

7. Silva JM, Caldeira AP. Avaliação para melhoria da qualidade da Estratégia Saúde da Família e a qualificação profissional. Trab. educ. saúde 2011; 9(1):95-108.

8. Venâncio SI, Silva AL, Martins MCFN, Martins PN, Figueiredo R, Rosa TEC, Bastos S. Avaliação para a Melhoria da Qualidade da Estratégia Saúde da Família - AMQ: estudo de implantação no Estado de São Paulo. São Paulo: Instituto de Saúde; 2008.

9. Instituto Brasileiro de Geografia e Estatística (IBGE). Cidades. [Internet]. Rio de Janeiro: IBGE; 2010. [acessado 2010 jul 1]. Disponível em: http://www.cidades. ibge.gov.br.

10. Minas Gerais. Secretaria de Estado de Saúde. Adscrição e população dos municípios por macrorregião e microrregião de saúde - Estimativa IBGE/TCU 2011. [acessado 2013 jan 26]. Disponível em: http://saude.mg.gov.br.

11. Fundação João Pinheiro. Centro de Estudos em Políticas Públicas. Informativo agosto/2008. [Internet]. Belo Horizonte: Fundação João Pinheiro; 2008. [acessado 2010 jul 1]. Disponível em: http://www.fjp.gov.br

12. Organização das Nações Unidas (ONU). Programa das Nações Unidas para o Desenvolvimento (PNUD). Atlas de Desenvolvimento Humano no Brasil. [acessado em 2010 jul 1]. Disponível em: http://www.pnud.org. br/atlas.

13. Malachias I, Leles FAG, Pinto MAS. Plano Diretor de Regionalização da Saúde de Minas Gerais. Belo Horizonte: Secretaria de Estado de Saúde de Minas Gerais; 2010.

14. Brasil. Ministério da Saúde (MS). Secretaria de Atenção à Saúde. Departamento de Atenção Básica. Saúde da Família. [Internet]. Brasília: Brasil, 2011. [acessado 2011 mai 9]. Disponível em: http://dab.saude.gov.br/ atencaobasica.php.

15. Sarti TD. Avaliação da Estratégia Saúde da Família no Espírito Santo utilizando o instrumento de Avaliação para Melhoria da Qualidade da Estratégia Saúde da Família (AMQ) [dissertação].Vitória: Universidade Federal do Espírito Santo; 2009.
16. Figueiredo AM, Kuchenbecker RS, Harzheim E, Vigo A, Hauser L, Chomatas ERV. Análise de concordância entre instrumentos de avaliação da Atenção Primária à Saúde na cidade de Curitiba, Paraná, em 2008. Epidemiol. Serv. Saúde 2013; 22(1):41-48.

17. Sarti TD, Campos CEAC, Zandonade E, Rushi GEC, Maciel ELN. Avaliação das ações de planejamento em saúde empreendidas por equipes de saúde da família. Cad Saude Publica 2012; 28(6):537-548.

18. Silva JM, Caldeira AP. Modelo assistencial e indicadores de qualidade da assistência: percepção dos profissionais da atenção primária à saúde. Cad Saude Publica 2010; 26(6):1187-1193.

19. Brasil. Ministério da Saúde (MS). Caderno de Auto-avaliação no 1: Gestão Municipal da Saúde. 3a ed. Brasília: MS; 2009.

20. Brasil. Ministério da Saúde (MS). Conselho Nacional de Saúde. Relatório Final da $14^{a}$ Conferência Nacional de Saúde: todos usam o SUS. Brasília: MS; 2012.

21. Pierantoni CR, Varella TC, Santos MR, França T, Garcia AC. Gestão do trabalho e da educação em saúde: recursos humanos em duas décadas do SUS. Physis 2008; 18(4):685-704.

22. Minas Gerais. Secretaria de Estado de Saúde (SESMG). Consolidado de pactuações de CIRs e CIRAs - reunião ordinária da CIB-SUS/MG - 16 de julho de 2014. [Internet]. Minas Gerais: Brasil, 2014. [acessado 2014 jul 26]. Disponível em:http://www.saude.mg.gov.br/sobre /institucional/apresentacao.

23. Arias EHL, Vitalino HA, Machado MH, Aguiar-Filho W, Cruz LAM. Gestão do trabalho no SUS. Cad RH Saúde 2006; 3(1):112-117.

24. Dinsdale GB, Manson DB, Schmidt F, Strickland T. Metodologia para medir a satisfação do usuário no Canadá: desfazendo mitos e redesenhando roteiros. Brasília: Escola Nacional de Administração Pública; 2000.

25. Lacerda WA, Santiago IMFL. A participação popular na gestão local do Programa Saúde da Família em Campina Grande, Paraíba. Rev. Katálysis 2007; 10(2):197-205.

26. Martins PC, Cotta RMM, Mendes FF, Franceschinni SCC, Priore SE, Dias G, Siqueira-Batista R. Conselhos de Saúde e a Participação Social no Brasil: matizes da utopia. Physis 2008; 18(1):105-121.

27. Brasil. Ministério da Saúde (MS). Conselho Nacional de Saúde. Diretrizes nacionais para o processo de educação permanente no controle social do SUS. Brasília: MS; 2006.

28. Cortes SMV. Construindo a possibilidade de participação dos usuários: conselhos e conferências no Sistema Único de Saúde. Sociologias 2002; 4(7):18-49.

29. Minas Gerais. Deliberação CIB-SUS/MG no 340, de 19 de abril de 2007. Altera o art. $3^{\circ}$ da Deliberação CIBSUS/MG no 287 de 17 de agosto de 2006. [Internet]. Minas Gerais: Brasil, 2007. [acessado 2011 out 04]. Disponível em: http://www.saude.mg.gov.br/atos_normativos/deliberacoes/2007/Del\%20340\%20alteracao\%20 da\%20Deliberacao\%20no\%20287.pdf .

30. Figueiredo PP, Cezar-Vaz MR, Soares JFS, Sena J, Cardoso LS. Processo de trabalho da estratégia saúde da família: a concepção de gestão que permeia o agir em saúde. Physis 2010; 20(1):235-259. 
31. Brasil. Ministério da Saúde (MS). Conselho Nacional de Secretarias Municipais de Saúde (CONASEMS). A Atenção Básica que queremos. Brasília: CONASEMS; 2011.

32. Ferla AA, Rocha CMF, Santos LM. Integração ensinoserviço: caminhos possíveis? Porto Alegre: Rede Unida; 2013.

33. Brasil. Ministério da Saúde (MS). Conselho Nacional de Secretários de Saúde (CONASS). A Gestão do Trabalho e da Educação na Saúde. Brasília: CONASS; 2011. $120 \mathrm{p}$.

34. Batista MJ, Gibilini C, Kobayashi HM, Ferreira LL, Souza MLR. Relato de experiência da interação entre universidade, comunidade e Unidade de Saúde da Família em Piracicaba, SP, Brasil. Arquivos em Odontologia 2010; 46(3):144-151.

35. Campos FC, Haddad AE, Wen CL, Alkmim MBM. Telessaúde em apoio à atenção primária à saúde no Brasil. Em: Santos AF, Souza C, Alves HJ, Santos SF, organizadores. Telessaúde - um instrumento de suporte assistencial e educação permanente. Belo Horizonte: UFMG; 2006. 59-74 p.

36. Silva GS. O processo de trabalho do coordenador municipal da Estratégia Saúde da Família [dissertação]. Belo Horizonte: Universidade Federal de Minas Gerais; 2009. 96 p.

37. Minas Gerais. Secretaria de Estado de Saúde de Minas Gerais. Resolução SES Nº 604 de 19 de Novembro de 2004. Dispõe sobre o Projeto Físico das Unidades Básicas de Saúde e estabelece outras providências. [Internet]. Minas Gerais: Brasil, 2004. [acessado 2011 out 04]. Disponível em: http://www.saude.mg.gov.br/ index.php?option $=$ com_gmg\&controller $=$ document\&id $=478$.

38. Minas Gerais. Secretaria de Estado de Saúde de Minas Gerais. Resolução SES/MG No 760, de 06 de outubro de 2005. Estabelece o incentivo, no âmbito do Programa Saúde em Casa, para a melhoria da infra-estrutura e qualidade do Sistema de Atenção Primária à saúde e define critérios para sua concessão. [Internet]. Minas Gerais: Brasil, 2005. [acessado 2011 out 04]. Disponível em: http://www.saude.mg.gov.br/images/documentos/ res_0760.pdf

39. Brasil. Ministério da Saúde (MS). Departamento de Atenção Básica. Secretaria de Atenção à Saúde. Saúde da Família no Brasil: uma análise de indicadores selecionados: 1998-2005/2006. Brasília: MS; 2008.

Article submitted 07/10/2014

Approved 09/02/2014

Final version submitted 09/23/2014 